\title{
Natriuretic Activity in Plasma and Urine of Salt-Loaded Man and Sheep
}

\author{
Jean E. Sealey, J. Dianne Kirshman, and John H. Laragh \\ From the Department of Medicine, Columbia University, College of \\ Physicians and Surgeons and the Presbyterian Hospital, New York 10032
}

A B S T R A C T The present study was designed to examine the question of whether or not there is a natriuretic hormonal substance involved in the renal regulation of sodium balance.

For this purpose, procedures for concentration and fractionation of plasma and urine samples and a sensitive bioassay for demonstrating changes in renal sodium excretion were developed. The natriuretic assay utilized rats with mild diabetes insipidus which were maintained in salt and water balance.

Using these approaches a natriuretic humoral substance was demonstrated in plasma and urine from normal man and sheep, and in patients with primary aldosteronism or essential hypertension.

It seems likely that this substance participates in day to day regulation of sodium balance because it was not detectable in sodium-depleted subjects and it consistently appeared in the sodium-loaded subjects.

The hormonal agent may not act immediately and its activity can be apparent for up to $3 \mathrm{hr}$. Full expression of its activity requires that the assay animals be appropriately volume expanded. This suggests that the increases in sodium excretion mediated by this hormonal substance depend in part on the coparticipation of other physical and perhaps humoral factors.

This natriuretic substance appears to be of large molecular weight or carried by a large molecule. The data suggest that it acts, at least in part, to block sodium reabsorption in a more distal portion of the tubule.

\section{INTRODUCTION}

In the last few years evidence has accumulated to suggest that changes in glomerular filtration rate or in the activity of the renin-angiotensin-aldosterone system are

This work was presented at the annual meeting of The American Society for Clinical Investigation, 5 May 1969, Atlantic City, N. J.

Received for publication 4 June 1969 and in revised form 15 July 1969. not in themselves sufficient to explain all of the situations involved in physiological regulation of renal sodium excretion. Experiments have been reported in which changes in both filtration rate and aldosterone secretion were eliminated as variables. Nonetheless, test subjects were able to respond to salt loading by excreting an increased amount of sodium (1-6). Such results, as well as observations in other clinical situations, have led to the postulation that at least one other factor (so-called "third factor") must act on the kidney in some way to facilitate sodium excretion (7).

The nature of these other factors is a subject of continuing controversy. It has been suggested that a hormone may be released which promotes renal sodium excretion (1, 8-11), perhaps by depressing proximal tubular sodium reabsorption $(8,12)$. Recent studies also indicate that intrarenal physical changes in the postglomerular circulation (13-15) and possibly distributional changes in intrarenal blood flow (16-18) might be important in determining sodium excretion.

It has been shown that salt loading with concurrent expansion of extracellular fluid depresses the reabsorption of sodium by the proximal tubule (19). However, changes in proximal tubular reabsorption per se seem insufficient to explain saline diuresis because when plasma volume is expanded by hyperoncotic solutions (20) proximal reabsorption is depressed without necessarily leading to an increase in sodium excretion.

The present study was designed to examine the question of whether or not there is a natriuretic hormonal substance involved in the regulation of sodium excretion. To this end we decided that a meaningful assay for such a substance must involve the demonstration of a significant change in the rate of sodium excretion in the final urine.

Our results demonstrate the existence of a humoral substance with different physicochemical properties and different physiological effects than those heretofore proposed. The agent was not detectable in sodium-depleted subjects, but invariably appeared in blood and 
TABLE I

Classification of Rats

\begin{tabular}{lcc}
\hline $\begin{array}{c}\text { Classification } \\
\text { of DI rats }\end{array}$ & Urine flow & Urine osmolarity \\
\hline & $\begin{array}{c}\text { \% of body } \\
\text { wt/day }\end{array}$ & mOsm/liter \\
High flow DI & $>30$ & $<300$ \\
Low flow & $<30$ & $300-1000$ \\
Low Osm hetero & $<20$ & $1000-1500$ \\
High Osm hetero & $<20$ & $>1500$ \\
\hline
\end{tabular}

$\mathrm{DI}=$ diabetes insipidus.

urine of salt-loaded humans or sheep. It has consistently produced an impressive natriuresis in the assay animal.

\section{METHODS}

\section{Bioassay procedure for detection of natriuretic activity}

Long-Evans rats with congenital diabetes insipidus were obtained from Dr. H. Valtin (21). Heterozygous females were bred with homozygous males and $150-$ to $350-\mathrm{g}$ animals were used for assays. Since the inherited trait is recessive each litter had to be evaluated for the presence and severity of diabetes insipidus (DI). Accordingly, each litter had to be evaluated for the presence of the defect. The 50 - to $100-\mathrm{g}$ rats were placed in metabolic cages for $24 \mathrm{hr}$ and the volume of water consumed and urine excreted (collected under mineral oil) were both measured. Urinary osmolarity was determined using an Advanced Instruments osmometer. Those animals whose urine volumes were greater than $30 \%$ of their body weight and with an osmolarity of less than $300 \mathrm{mOsm} /$ liter were classified as "high flow" diabetes insipidus (DI) rats. The rest of the animals were classified according to Table I. All animals, except the "high Osm heteros" were routinely used for assay. The rats were prepared by injecting $5 \mathrm{mg} / 100 \mathrm{~g}$ sodium pentobarbital (Diabutal) and $0.13 \mathrm{mg} / 100 \mathrm{~g}$ atropine intraperitoneally. "High flow" rats often required much less anesthesia. Both the bladder and the jugular vein were catheterized with polyethylene PE 90 and PE 10, respectively, and a tracheostomy was performed (PE 240). The animal was then given slowly by stomach tube (PE 90$)$ up to $7 \frac{1}{2} \%$ of its body weight of a dilute solution of sodium chloride $(20 \mathrm{mEq} /$ liter $)$. Much less than this was required to induce water diuresis in high flow rats. The rat was then placed on a balance located over a turntable. ${ }^{1} 10$-min urine collections were made and the fluid lost was quantitatively replaced, automatically maintaining the weight of the animal by the oral administration of a 10 $\mathrm{mEq} /$ liter solution of sodium chloride (22). The replacement fluid also contained pentobarbital $18 \mathrm{mg} / 100 \mathrm{ml}$. With this system fluid balance is held constant throughout the day. Because the usual tendency is for control rates of urine flow to increase during the day (e.g. from 150 to as high as 300 $\mu 1 / \mathrm{min})$, this system has the potential disadvantage of increasing the sodium intake and therefore the control sodium output as the day proceeds. Possibly a more desirable system would be one in which sodium as well as water was automatically balanced. For every $10 \mathrm{~min}$ period, urine flow, and

\footnotetext{
${ }^{1}$ Laboratory Concepts, Inc., Bronx, N. Y.
}

sodium and potassium excretion were monitored using an I.L. flame photometer.

Ordinarily from 2 to $4 \mathrm{hr}$ elapsed before the first test sample was injected into the jugular vein. This preparation time was required for anesthesia, operating procedures, administration of the oral load, the achievement of an adequate urine flow, and the establishment of a stable rate of sodium excretion. When salt and water excretion appeared constant, a bolus of $0.5 \mathrm{ml}$ of isotonic saline was routinely injected. Usually this produced no change in urine sodium excretion. However, if this procedure increased urinary sodium significantly, the animal was discarded. The validity of this approach was confirmed by the fact that less than $5 \%$ of the animals had to be subsequently discarded because of the development of an unsteady rate of sodium excretion.

The unknowns were given either as a bolus in $0.1-0.5 \mathrm{ml}$ or occasionally as a constant infusion for $30 \mathrm{~min}$ at $\mathbf{0 . 0 2}$ $\mathrm{ml} / \mathrm{min}$. Positive natriuretic responses were compared with the response to a similar volume obtained from the same fraction from the same subject when not salt loaded, and also with the response to a similar volume of isotonic saline. Sensitivity of the assay, i.e. the degree of natriuretic response induced, seemed related to technical factors as well as to the general health and preexisting state of salt balance in the test animals. Insensitivity and unsteady control periods could be caused by fall in body temperature below $97^{\circ} \mathrm{F}$, by too much anesthetic agent, or by occult bleeding. After injection of each test sample the jugular vein was routinely cleared with $0.1 \mathrm{ml}$ of heparin solution $10 \mathrm{U} / \mathrm{ml}$.

Rats with "high flow" diabetes insipidus were found to be relatively insensitive when compared to either the low flow or the heterozygous animals. The reason for this was not entirely clear, but we have suspected that it is due to preexisting sodium depletion. This suspicion is based on the fact that control rates of urinary sodium excretion were lower in the high flow animals and were usually less than 0.5 $\mu \mathrm{Eq} / \mathrm{min}$ as compared with $0.5-2 \mu \mathrm{Eq} / \mathrm{min}$ in the other two groups. Sensitivity could often be restored by increasing the oral sodium load, but this procedure had the disadvantage of occasionally causing a fluctuating and unsteady rate of urinary sodium excretion. Further evidence for a state of relative sodium depletion of the high flow diabetic animals derives from measurements of plasma renin. In six measurements from each group renin activity in the high-flow animals was about twice as high, 15 as against $6 \mathrm{ng} / \mathrm{ml}$ per hr angiotensin formed. These data will be elaborated elsewhere. A recent report also indicates that these animals are volume depleted (23).

Because of the relative insensitivity of the high flow animals, most of the assays were carried out in the "low flow" D.I. and in "low Osm heterozygotes." While these latter animals do have a partial capacity to concentrate the urine, they perhaps provide the advantage of being less able than normal animals to release endogenous antidiuretic hormone (ADH) when a noxious injection is given.

\section{Experimental protocol for collection of samples}

\section{Human Studies}

Studies in which dietary sodium was manipulated. Three normal subjects were given furosemide $40 \mathrm{mg}$ orally in three doses on day 1 and then placed on a constant low sodium diet ( $<10 \mathrm{mEq} \mathrm{NaCl} /$ day) for the ensuing 7 days. 24-hr urines were refrigerated during collections on days 5,6 , and 7. Aliquots were removed for measurement of urinary sodium and potassium and for aldosterone excretion (24). The rest of each sample was either stored frozen or lyo- 
TABLE II

Location of Active Fractions

\begin{tabular}{lcccccc}
\hline & & \multicolumn{5}{c}{ Fraction No. } \\
\cline { 3 - 6 } Gel & $\begin{array}{c}\text { Mol wt. fraction- } \\
\text { ation range }\end{array}$ & $\begin{array}{c}\text { I, pro- } \\
\text { tein peak }\end{array}$ & II & III & $\begin{array}{c}\text { IV. } \\
\text { salt } \\
\text { peak }\end{array}$ \\
\hline P2 & $2000-200$ & $+?$ & & & & - \\
G25F & $5000-1000$ & +++ & - & - & - & - \\
G75 & $70,000-3000$ & ++ & ++ & - & - & - \\
G100 & $150,000-4000$ & + & + & ++ & - & - \\
\hline
\end{tabular}

philized in preparation for fractionation and assay for natriuretic activity. $20 \mathrm{ml}$ of venous blood were collected in ethylenediaminetetraacetate (EDTA) $(0.003 \mathrm{~mole} / \mathrm{liter})$ on these days and the plasma stored frozen for measurement of plasma renin (25) and angiotensin (26). On day 7, an extra $40 \mathrm{ml}$ of blood was obtained and the plasma saved for work-up for natriuretic assay. The following week $10 \mathrm{~g}$ $\mathrm{NaCl}$ in 1.0-g gelatin capsules was added to the diet and urine and blood samples were collected again in the same manner on days 5,6 , and 7 .

Acute studies of the effect of saline infusion. Six normal subjects and five patients with uncomplicated essential hypertension and one hypertensive patient with renal artery stenosis were given 2 liters of isotonic saline intravenously over a $1 \mathrm{hr}$ period. The subjects had been maintained on normal unrestricted diets and were receiving no medications. They were fasting and recumbent and were given a $500 \mathrm{ml}$ oral water load 2-3 $\mathrm{hr}$ before starting the infusion. Urine collected for the $2 \mathrm{hr}$ before starting the infusion was used as the control. A second urine collection included the $3 \mathrm{hr}$ period after the infusion was started. $60 \mathrm{ml}$ of venous blood were collected into EDTA immediately before starting the infusion and again $1 \mathrm{hr}$ later at the end of the infusion.

Four patients with primary aldosteronism subsequently proven at operation were given 4 liters of saline intravenously over a $2 \mathrm{hr}$ period. In these patients control period urine collections were not made, but venous blood samples were collected as above.

\section{Studies in Shemp}

Two Dorset female sheep each weighing approximately $40 \mathrm{~kg}$ were maintained on a diet of alfalfa and Purina Dairy Conditioner Chow. After 2 wk of equilibration 24-hr urines were collected from each animal for 2 consecutive days and $500 \mathrm{ml}$ of heparinized jugular vein blood were collected from each. Sheep 59 was then given $0.45 \% \mathrm{NaCl}$ as drinking water whereas sheep 60 was maintained on tap water. After 2 months on this regimen the drinking water of sheep 59 was increased to $0.68 \%$ saline and sheep 60 was given $0.45 \%$ saline for the $3 \mathrm{rd}$ month. In the next period (4th month) both sheep were returned to tap water. Jugular or femoral venous blood and $24 \mathrm{hr}$ urine samples were collected at least once a week during the various study periods.

\section{Fractionation procedures and preparation of samples for assay}

The objectives of the fractionation procedures were $(a)$ to eliminate salt and small molecules, $(b)$ to concentrate as much as possible, and (c) to fractionate according to molecular size substances present in plasma or urine.

In the initial studies $24 \mathrm{hr}$ urine samples were lyophilized (lyophilizer obtained from Virtis Co., Gardiner, N. Y.) The sample was reconstituted in $100 \mathrm{ml}$ of $0.1 \mathrm{M}$ acetic acid and centrifuged for $10 \mathrm{~min}$ at $5000 \mathrm{rpm}$. For desalting, the supernatant was applied to a $5 \times 30 \mathrm{~cm}$ column of polyacrylamide gel (Bio-Gel P2). The column was developed with $0.1 \mathrm{M}$ acetic acid. Three fractions were collected; the first, about $400 \mathrm{ml}$, comprised all of the material eluted before the salt peak. This fraction is thought to contain all material of mol wt $>200$ except for those substances which may be specifically absorbed or retarded by the gel. The second fraction, about $800 \mathrm{ml}$, containing the salt peak was discarded. A third fraction collected after the salt peak of about $1200 \mathrm{ml}$ was lyophilized in preparation for assay. The first fraction was also lyophilized to dryness and then dissolved in $24 \mathrm{ml}$ of $0.1 \mathrm{M}$ acetic acid containing $0.015 \mathrm{M} \mathrm{NaCl}$ and centrifuged for $10 \mathrm{~min}$ at $5000 \mathrm{rpm}$ in preparation for further

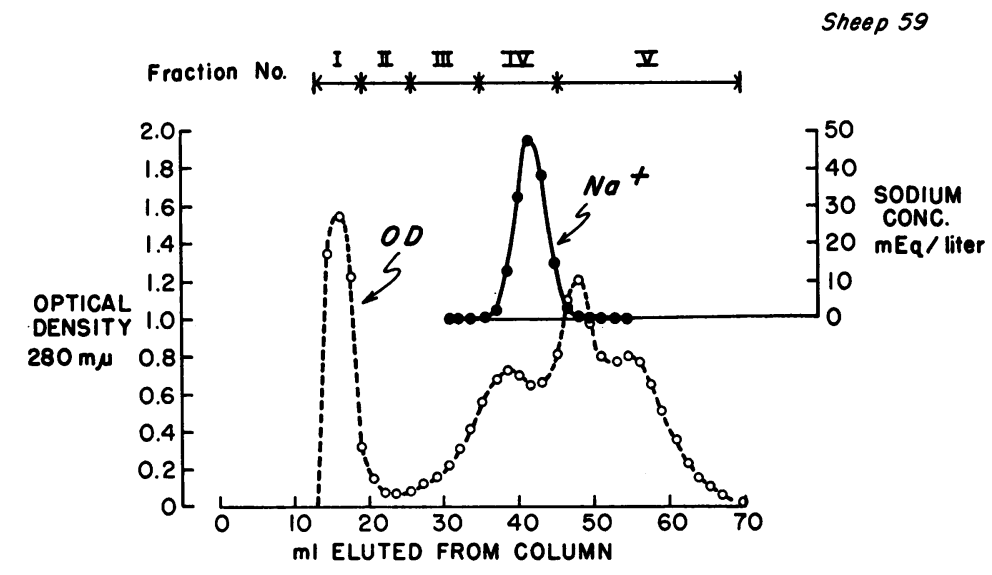

FIGURE $1 \frac{1}{2}$ of the high molecular weight fraction of 24-hr sheep urine taken from a Bio-Gel P2 column was here applied to a G75 Sephadex column $(1.5 \times 25 \mathrm{~cm}), 0.1 \mathrm{~m}$ acetic acid buffer. A plot is shown of the absorption at $2 \varepsilon 0 \mathrm{~m} \mu$ and the sodium concentration of the eluate as contained in fractions $I$ to $\mathrm{V}$. 


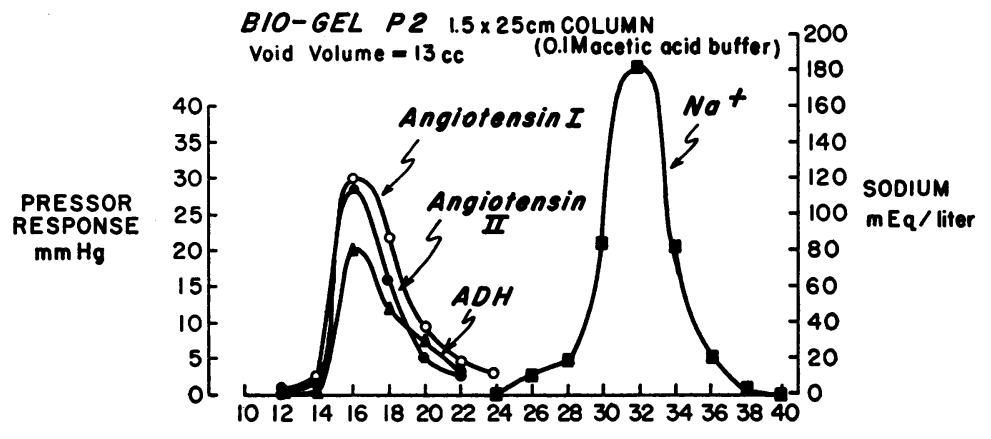

G25F SEPHADEX $2.5 \times 35 \mathrm{~cm}$ (0.1 M acetic acid buffer)

Void Volume $-62 \mathrm{cc}$

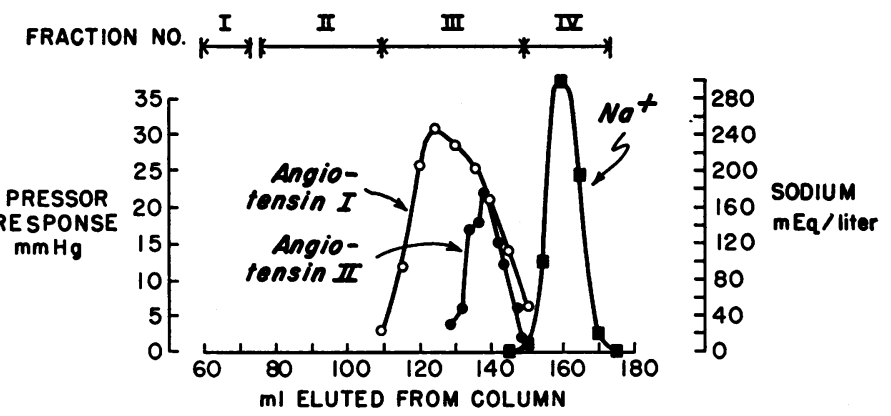

FIgURE 2 Location of vasoactive peptides during fractionation on BioGel P2 and on Sephadex G25F. $750 \mathrm{ng}$ of angiotensin I and angiotensin II dissolved in $2 \mathrm{cc}$ of isotonic saline were applied at different times to each column and their location identified by the pressor activity in a standard rat pressor bioassay. 10 pressor $U$ of vasopressin were also applied to the Bio-Gel P2 column and located by its pressor activity.

fractionation. The osmolality of the supernatant solution was of the order of $200 \mathrm{mOsm} /$ liter. $3 \mathrm{ml}$ of this supernatant was applied to each of the following three $1.5 \times 25 \mathrm{~cm}$ Sephadex columns, G25F, G75, and G100. For developing the column $0.1 \mathrm{M}$ acetic acid was used. The eluate from each of these three columns was collected in 2-ml aliquots and divided into five fractions after discarding the void volume. Fraction I in each case contained those substances which were completely excluded by the gel (Table II). The location of this fraction was determined by its absorption of $280 \mathrm{~m} \mu$ in a Gilford spectrophotometer (Fig. 1). Fraction IV was identified in each case as containing the salt peak and fraction V contained other substances eluted after the salt peak which exhibited absorption at $280 \mathrm{~m} \mu$. Fractions II and III, collected between fractions I and IV, were arbitrarily divided, as illustrated in Fig. 1. $10 \mathrm{mg}$ of bovine serum albumen and $0.05 \mathrm{ml}$ of $1 \mathrm{~N}$ mercaptoacetic acid was added to each of these fractions before lyophilization and storage at $-20^{\circ} \mathrm{C}$. It was found that these two procedures prevented loss of activity during storage. Stored in this way activity has been preserved for longer than a month.

On the day of assay the samples were reconstituted in 0.3 $\mathrm{ml}$ of $0.45 \%$ saline. $0.1 \mathrm{ml}$ representing the extract from $1 \mathrm{hr}$ of urine was injected into each of two assay animals. Insofar as was possible, each of the five fractions from any given column was injected into the same assay animal.

Essentially the same fractionation and separation procedures as those described for urine were employed in work- ing up plasma samples. However, to deproteinize plasma the samples were first diluted with an equal volume of water, the $\mathrm{pH}$ was reduced to 5.5 with $10 \%$ acetic acid, and the samples were then placed in a boiling water bath for $20 \mathrm{~min}$. This approach was used after it had been established that (a) boiled urine did not lose natriuretic activity and $(b)$ the activity in positive plasma samples remained after boiling. After boiling, the denatured proteins were removed by centrifugation, and the supernatant was lyophilized and subsequently treated in the same manner as described for the urine samples.

The separation procedures utilized were further characterized by locating the fractions which contained the small peptides, angiotensin I, angiotensin II, and arginine vasopressin (Fig. 2). These materials were recovered close to the salt peak on G25 and with the void volume on Bio-Gel P2. Clearly these peptides were not found associated with any of those fractions which exhibited natriuretic activity. As shown in Table II, positive assays for natriuretic activity have only been observed in fraction I from G25F, in fractions I and II of G75, and in fraction III of G100. Because of these observations and because it was possible to demonstrate that small vasoactive peptides can be easily separated from fraction I even when using a G25 column alone (Fig. 2), a simplified procedure was worked out for the rountine fractionation of blood and urine. 


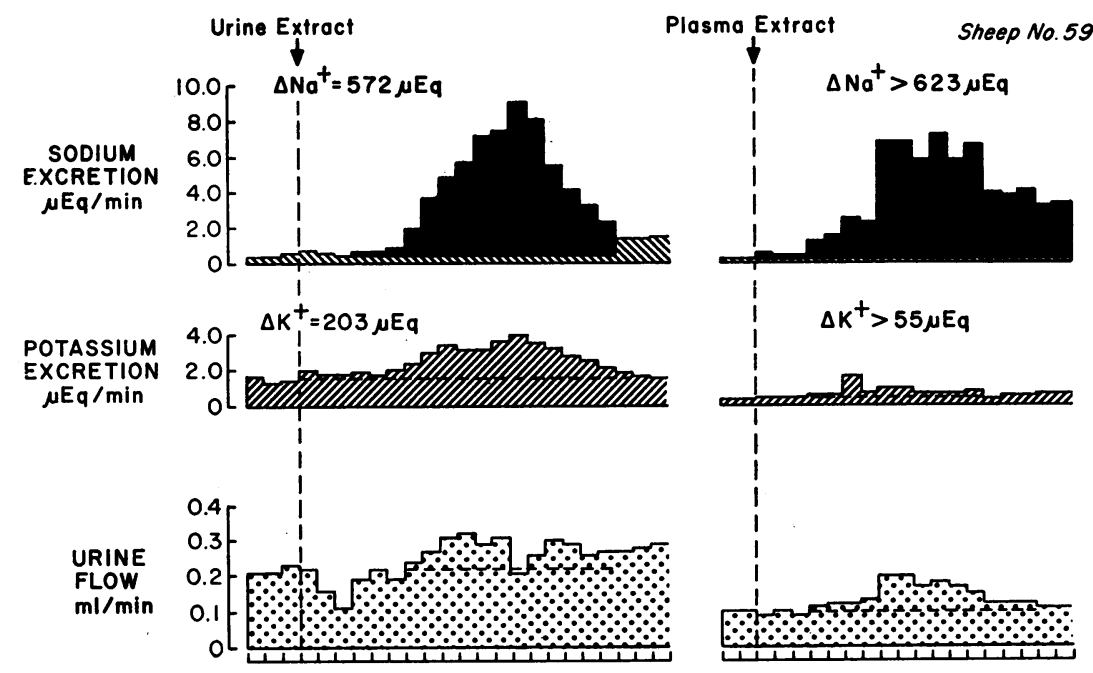

10 MINUTE URINE SAMPLE

FIgURE 3 Natriuretic responses are shown as observed in two different rats given an extract of urine or of plasma from sheep 59 which had been drinking $0.45 \%$ saline.

Routine procedures for fractionation and preparation of urine and blood

The 24-hr urines were lyophilized and reconstituted in $0.1 \mathrm{M}$ acetic acid ( $4 \mathrm{ml} / \mathrm{hr}$ of urine) and centrifuged $10 \mathrm{~min}$ at 5000 $\mathrm{rpm}$. The supernatant was applied to a G50 medium mesh (M) column $(2.5 \times 60 \mathrm{~cm})$. The fractions eluted before the salt peak were combined and bovine albumen $(0.5 \mathrm{mg} / \mathrm{hr}$ of sample) plus one drop of $1.0 \mathrm{~N}$ mercaptoacetic acid was added.
These fractions were lyophilized and the white fluffy material was weighed. $2 \mathrm{hr}$ of sample (assuming no losses) was weighed and reconstituted in $0.2 \mathrm{ml}$ of $0.45 \%$ saline. $0.1 \mathrm{ml}$ of the solution was usually injected into the assay animal. Initially the same amount of extract was dissolved in up to $0.5 \mathrm{ml}$. However in most of the later studies $0.1 \mathrm{ml}$ was routinely injected. The osmolarity of this final solution was repeatedly found to be in the region of $200 \mathrm{mOsm} / \mathrm{liter}$. Sheep urine was more difficult to purify than human urine. Therefore,

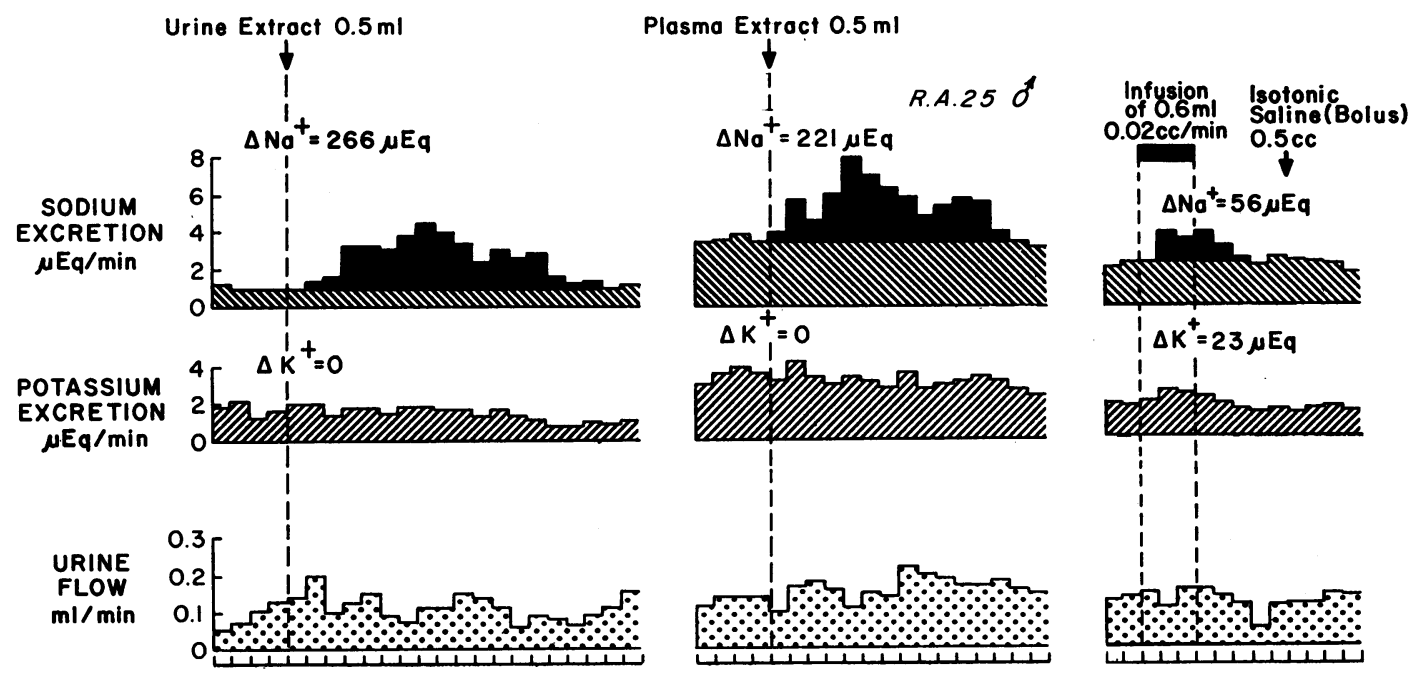

10 MINUTE URINE SAMPLES

FIgURE 4 Human urine and plasma extracts taken from a salt-loaded patient with primary aldosteronism and passed through Sephadex G50M and G75, respectively, were assayed in two different rats. Significant natriuresis was produced in both. Urine flow and potassium excretion did not change in two of three assays. The injection of a bolus of $0.5 \mathrm{ml}$ of plasma extract elicited a greater natriuretic response than the constant infusion of $0.6 \mathrm{ml}$ of the same extract tested in the same rat over $30 \mathrm{~min}$. 


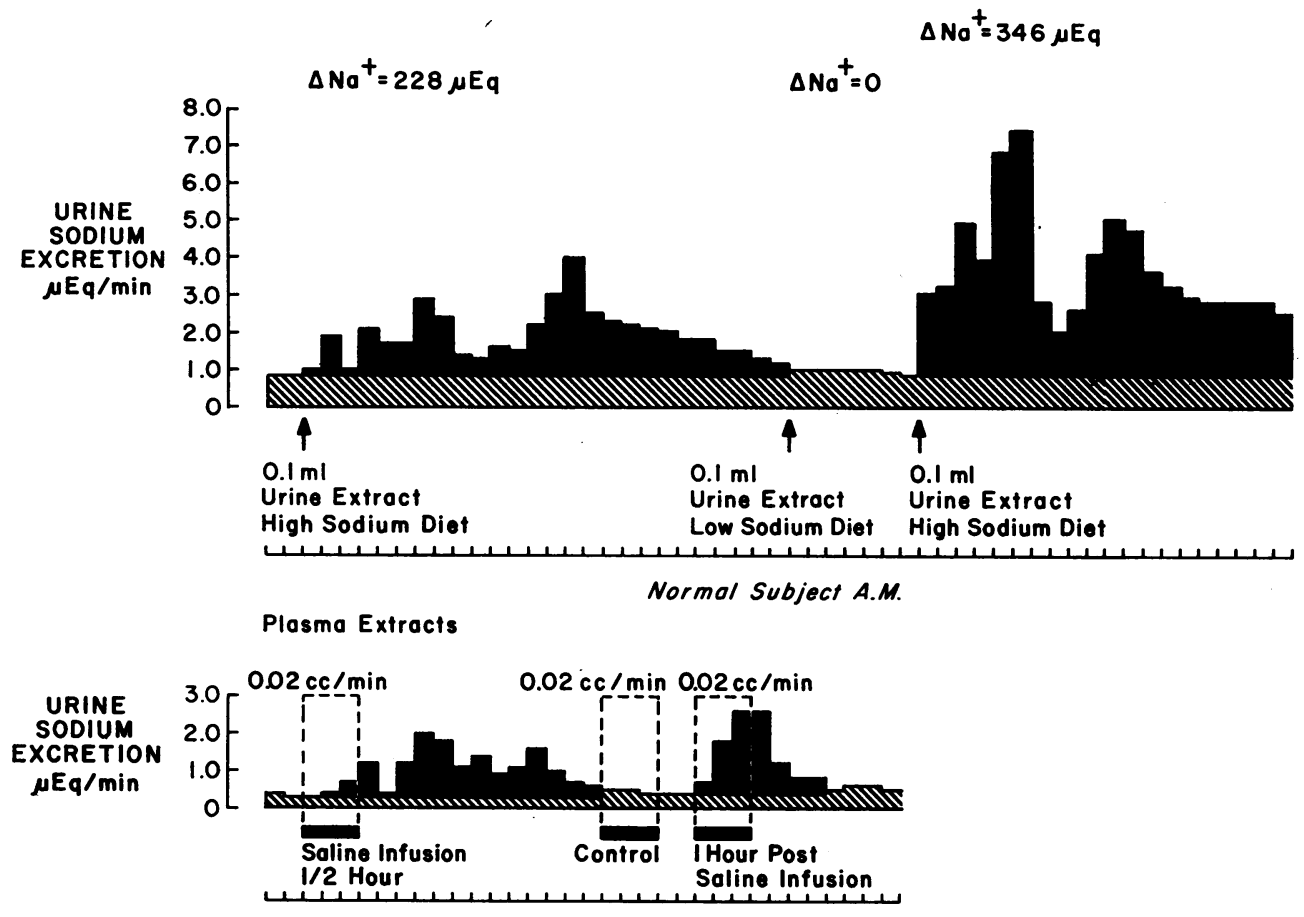

10 MINUTE URINE SAMPLES

FIGURE 5 Upper panel : assays of urine samples obtained from a normal subject during sodium depletion and sodium loading. The samples were given by injection of a bolus. The second assay animal (lower panel) was given by infusion samples of plasma extracts from a normal subject drawn before, during, and after an infusion of 4 liters of isotonic saline given over $1 \mathrm{hr}$. In both assays the first positive extract elicited a long low response in the assay animal whereas a later injection or infusion elicited a much more rapid response. In the first assay in which the same injection was given twice the second response involved a greater excretion of sodium. In neither assay did the control extract cause any change.

before the G50 M column the sample was first applied to a $5 \times 30 \mathrm{~cm}$ Bio-Gel P2 column as described above. The lyophilized and deproteinized $20-\mathrm{ml}$ plasma samples were reconstituted in $2 \mathrm{ml} 0.1 \mathrm{M}$ acetic acid and applied to a $1.5 \times 25 \mathrm{~cm}$ G75 Sephadex column. All fractions up to the salt peak were combined. For storage $2 \mathrm{mg}$ bovine albumen and one drop $1.0 \mathrm{~N}$ mercaptoacetic acid were added and the samples were lyophilized. The lyophilized fractions were reconstituted in $0.2 \mathrm{ml} 0.45 \%$ saline on the day of assay and $0.1 \mathrm{ml}$ was injected into an assay animal.

\section{RESULTS}

Responses observed in the bioassays. Detailed descriptions of the various response patterns as observed in 11 different assay animals are presented in Figs. 3-8. Taken altogether the steadiness of the baseline control values for sodium and water excretion is quite apparent. The lack of response to control injection of a bolus of $0.5 \mathrm{ml}$ isotonic saline is also illustrated (Figs. 4 , 6 , and 7 ).

In Figure 3 impressive natriuretic responses rather similar in magnitude and duration are shown as ob- served in two different assay animals. One was given $0.1 \mathrm{ml}$ of urine extract and the other $0.5 \mathrm{ml}$ of a plasma extract from a sheep which had been drinking $0.45 \%$ $\mathrm{NaCl}$. The $24 \mathrm{hr}$ sodium excretion for this sheep was $352 \mathrm{mEq}$ in the urine sample from which this activity was extracted. In this particular pair of responses urine flow and potassium excretion also were increased, but in other assays these latter two effects did not always accompany the induced natriuresis.

Fig. 4 presents results of assays of similar extracts of plasma and urine which were obtained from a patient with primary aldosteronism during saline infusion. A natriuretic agent with similar properties was extractable from both the plasma and urine of this patient. In two of these three assays neither urine flow nor potassium excretion were changed by the natriuretic agent. Also shown (Fig. 4) are results of assays of the same positive plasma extract given as a bolus and then as a constant infusion. There was a slightly greater response to the bolus even though somewhat more material was given 
by infusion. In assays of samples from sheep (Fig. 3) or man (Fig. 4) the induced natriuretic response lasted for up to $3 \mathrm{hr}$. The onset of the effect was apparent from 10 to $60 \mathrm{~min}$ after the injection.

Fig. 5 illustrates the variations which were observed in onset, magnitude, and duration of natriuretic responses. These two studies are representative of a frequently observed phenomenon, i.e., for the responses to the same positive sample to become more immediate and pronounced when repeated'during the course of the day. Nonetheless, the response to control extracts of either plasma or urine obtained during sodium depletion remained negative.

Fig. 6 illustrates the lower control rate of sodium excretion and the relative insensitivity of a "high flow" diabetic rat to a sample whcih subsequently produced a striking natriuresis when tested in a "low Osm hetero" animal. Fig. 7 illustrates an antidiuretic action which has been observed to accompany some of the positive responses obtained from sheep urine. The effect has not been observed in active material from human sources. It may be induced via an endogenous release of $\mathrm{ADH}$ because "high flow" rats with no vasopressin reserve did not exhibit this antidiuresis. Fig. 8 presents the greatest response obtained in assays of extracts from

Rat Assay 2/6

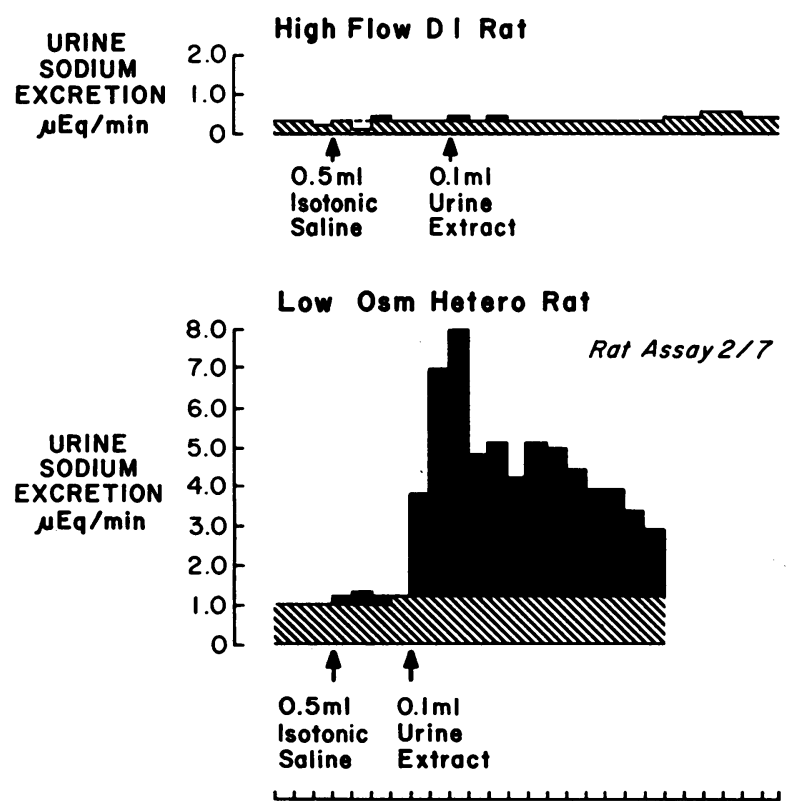

10 MINUTE URINE SAMPLES

Figure 6 The same urine extract from a salt loaded subject was injected into a "high flow" D.I. rat with a basal sodium excretion of $0.2 \mu \mathrm{Eq} / \mathrm{min}$ and then on the next day to a "low Osm hetero." In the second rat the $\mathrm{U}_{\mathrm{Na}} \mathrm{V}$ increased from $1.2 \mu \mathrm{Eq} / \mathrm{min}$ to $8.0 \mu \mathrm{Eq} / \mathrm{min}$ while there was no change elicited in the "high flow" rat.
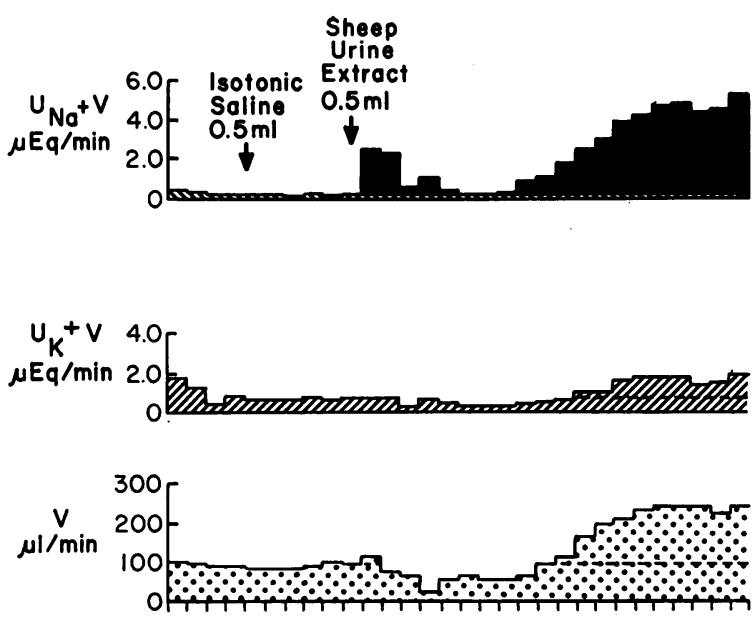

10 MINUTE URINE SAMPLES

FIgURE 7 Antidiuretic property of active sheep urine extract from a G25F column caused depression of urine flow for $80 \mathrm{~min}$. The $\mathrm{U}_{\mathrm{Na}}{ }^{+} \mathrm{V}$ fell transiently during antidiuresis. An antidiuresis was also observed to a lesser extent in sheep fractions eluted from a G75 column.

man. The magnitude of this response is similar to what was observed in samples collected from saline-loaded sheep.

Summary of assay results. In Tables III, IV, and V the results of all assays for natriuretic activity are presented. All of the data from Tables III and IV are also presented graphically in Fig. 9. In Table III are presented the urinary volume and electrolyte values collected from three normal subjects during alterations in sodium balance. Also presented are the results of up to four assays of the extracts of these urines and of plasma samples collected during this time. The assays represent the injection of 1 -hr of urine extract or the equivalent of $10 \mathrm{ml}$ of plasma extract. The cumulative sodium and potassium losses of the assay animal and also the initial and maximum rates of sodium excretion are shown for each assay.

Table IV summarizes the saline infusion studies. In most cases the urine flow and the rates of sodium and potassium excretion from both the control period and from the $3 \mathrm{hr}$ period after the saline infusion are presented. The assay results again represent the changes in the urinary electrolytes due to the injection of urine or plasma extracts into the assay animal. However in this case only a $\frac{1}{2}$-hr urine extract was assayed because in the control period these subjects were not sodium depleted. This was done because natriuretic activity is sometimes present in 1-hr urine extracts derived from subjects not on a low salt diet.

In Table $\mathrm{V}$ are the urinary electrolytes of the sheep drinking either tap water or half isotonic saline. The rat assay results represent the injection of either 1-hr urine 


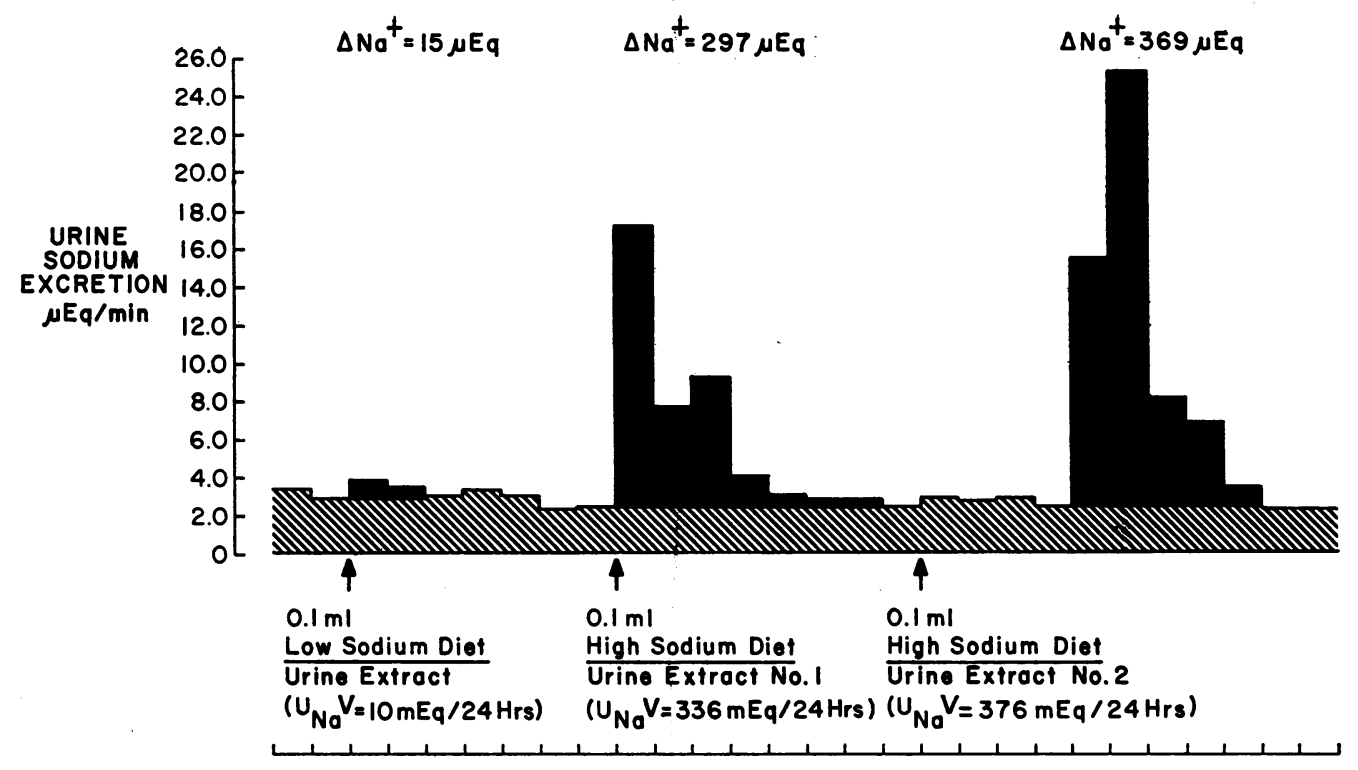

IO MINUTE URINE SAMPLES

FIGURE 8 Bioassay of urine extracts from a normal subject on high and low sodium diets. Urine extracts from a normal subject induced marked natriuresis in the assay rat when prepared from samples obtained during maintenance on a high sodium diet. Samples prepared in the same way but collected during sodium deprivation produced no effect.

extract or $10 \mathrm{ml}$ of plasma. The plasma drawn from the jugular vein seemed to exhibit more natriuretic activity than the femoral sample; however, from a single study the meaning of the difference is questionable.

The summary presentation of Fig. 9 in which all assay data are presented is noteworthy because in all of 26 assays collected as controls during sodium depletion or before saline infusion virtually no increase in sodium excretion was produced in the assay rat. In contrast, samples collected after a high sodium diet or at the end of a saline infusion nearly always produced increases in sodium excretion in the test animals. Whereas in the positive group there appears to be some overlap into the control range (Fig. 9), inspection of Tables III and IV indicates that in no case in paired assays did the control sample induce more natriuresis than that derived from saline infusions or a high sodium diet.

Nature of the effect of the natriuretic substance on the renal excretion of salt and water. In Fig. 10 an analysis is presented for all positive assays of the relationship between the per cent change in urine flow and the associated per cent change in the rate of sodium excretion the latter plotted logarithmically on the abscissa. The curved line represents the plot inscribed by a natriuresis in which the urinary sodium concentration remains unchanged from control values. Because in all assays the responses fall well to the right of this line it is apparent that the induced natriuresis was largely accounted for by an increased sodium concentration.
Moreover, there was no apparent correlation between the changes in urine flow and in the rate of sodium excretion.

Effects of potassium excretion. During the natriuresis induced by a positive sample potassium excretion tended to increase much more consistently than did flow (Tables III-V). Thus in about $2 / 3$ of 50 positive assays some kaliuresis was observed. The kaliuresis was usually mild but in a number of instances the cumulative losses exceeded $50 \mu$ Eq.

\section{DISCUSSION}

The present work provides strong support for the idea that a natriuretic hormonal substance exists which is involved in the day to day physiological regulation of sodium balance. This view is supported mainly by $(a)$ the demonstration of a substance in both plasma and urine which produces marked increases in the rate of sodium excretion in the final urine of an appropriately prepared assay animal, and by $(b)$ the demonstration that the appearance of hormonal activity is directly related to the state of sodium balance and the rate of sodium excretion in both man and sheep.

To appraise the validity of this interpretation it is appropriate to evaluate the general approaches utilized in this study. It was recognized at the outset that if a natriuretic hormone does in fact exist, it is probably present in blood and urine in very minute amounts. Such 
TABLE III

Summary of Assays of Samples Collected

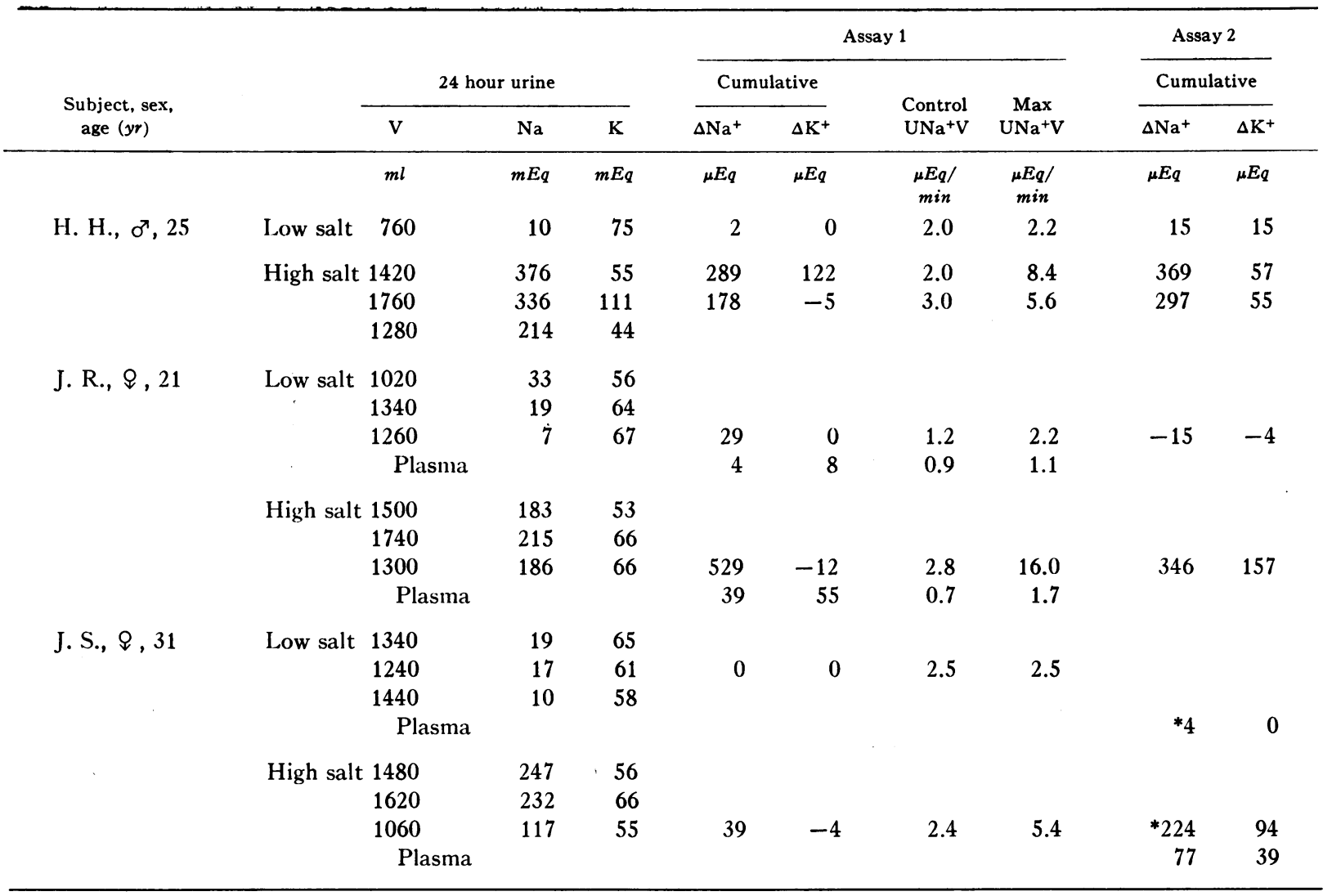

$\mathrm{Max}=$ maximum $; \mathrm{UNa}^{+} \mathrm{V}=$ rate of urinary sodium excreation.

* 2-hr urine injected.

is the case with aldosterone, for example. Here, in order to have any chance at all of detecting aldosterone in a rate bioassay, at least 2 liters of blood or half a liter of a normal day's urine would be required. With this in mind a number of approaches were adopted to multiply the sensitivity of the detecting systems. These approaches all operated to increase the concentration of the postulated hormone and to amplify the sensitivity of the assay animal. Plasma and urine were collected under circumstances of sodium excess. At first, salt-loaded patients with primary aldosteronism were chosen because here the sodium-retaining hormone maintains an increased body sodium content which induces the secondary renal response of "escape," or an increased capacity to excrete salt. 24-hr urine samples and up to $50 \mathrm{ml}$ of plasma were lyophilized. In order to concentrate the substance further, by as much as 2000 -fold, the samples were desalted and fractionated by gel filtration procedures. Another multiplier involved the preparation of samples from larger species for assay in small animals.
In addition, the development of a sensitive and relevant bioassay appeared crucial for demonstration of this natriuretic activity. Animals with diabetes insipidus were used because of the technical advantage of their higher urine flow and their inability to release $\mathrm{ADH}$ during an assay. After numerous trials, it was appreciated that those animals with the full-blown diabetic tendency were often sodium-depleted and were the least likely of the strain to respond to a natriuretic stimulus. It was further learned, as indicated above, that careful attention to sodium balance greatly amplifies the sensitivity of the test animals. Sensitivity was greatly improved in animals excreting somewhat more than $0.5 \mu \mathrm{Eq}$ of sodium/ min. While this might appear to be a relatively high rate for such a small animal, their endogenous natriuretic stimulus is probably not maximal perhaps because volume expansion was achieved with water loading instead of by sodium loading. Thus when our animals were expanded with saline they became insensitive to the natriuretic humoral substances. Using "low flow" diabetic animals maintained in salt balance, the magnitude of the 


\begin{tabular}{|c|c|c|c|c|c|c|c|c|c|}
\hline \multicolumn{2}{|c|}{ Assay 2} & \multicolumn{4}{|c|}{ Assay 3} & \multicolumn{4}{|c|}{ Assay 4} \\
\hline \multirow{2}{*}{$\begin{array}{l}\text { Control } \\
\mathrm{UNa}^{+} \mathrm{V}\end{array}$} & \multirow{2}{*}{$\underset{\mathrm{UNa}^{+} \mathrm{Max}}{\operatorname{Max}}$} & \multicolumn{2}{|c|}{ Cumulative } & \multirow{2}{*}{$\begin{array}{l}\text { Control } \\
\text { UNa }^{+} \mathbf{V}\end{array}$} & \multirow{2}{*}{$\underset{\mathrm{UNa}^{+} \mathbf{M a x}}{\operatorname{Max}}$} & \multicolumn{2}{|c|}{ Cumulative } & \multirow{2}{*}{$\begin{array}{l}\text { Control } \\
\mathrm{UNa}^{+} \mathrm{V}\end{array}$} & \multirow{2}{*}{$\begin{array}{c}\mathrm{Max} \\
\mathrm{UNa}^{+} \mathrm{V}\end{array}$} \\
\hline & & $\Delta \mathrm{Na}^{+}$ & $\Delta \mathrm{K}^{+}$ & & & $\Delta \mathrm{Na}^{+}$ & $\Delta \mathrm{K}^{+}$ & & \\
\hline $\begin{array}{l}\mu E q / \\
\min \end{array}$ & $\begin{array}{l}\mu E q / \\
\min \end{array}$ & $\mu E q$ & $\mu E q$ & $\begin{array}{l}\mu E q / \\
\min \end{array}$ & $\underset{\min }{\mu E q /}$ & $\mu E q$ & $\mu E q$ & $\underset{\min }{\mu E q /}$ & $\begin{array}{c}\mu E q / \\
\min \end{array}$ \\
\hline 2.9 & 3.8 & 27 & 0 & 2.6 & 3.7 & 19 & 0 & 2.2 & 2.8 \\
\hline $\begin{array}{l}2.4 \\
2.4\end{array}$ & $\begin{array}{l}25.2 \\
17.1\end{array}$ & $\begin{array}{l}196 \\
111\end{array}$ & $\begin{array}{r}0 \\
18\end{array}$ & $\begin{array}{l}0.4 \\
2.6\end{array}$ & $\begin{array}{l}5.4 \\
6.3\end{array}$ & & & & \\
\hline & & & & & & 404 & 49 & 1.2 & 7.3 \\
\hline 1.2 & 0.8 & 18 & 28 & 1.1 & 2.4 & 0 & 0 & 1.1 & 1.1 \\
\hline & & 98 & 39 & 0.6 & 3.0 & & & & \\
\hline 0.8 & 7.5 & 179 & 20 & 1.1 & 12.3 & 876 & 9 & 3.6 & 11.9 \\
\hline 1.9 & 2.2 & 27 & 20 & 0.9 & 1.5 & 10 & 0 & 1.0 & 2.0 \\
\hline $\begin{array}{l}1.3 \\
1.9\end{array}$ & $\begin{array}{l}4.8 \\
4.6\end{array}$ & 221 & 24 & 0.5 & 3.4 & 339 & 0 & 2.1 & 4.7 \\
\hline
\end{tabular}

positive responses in some animals was quite impressive, involving the loss of more than $500 \mu \mathrm{Eq}$ or perhaps more than $5 \%$ of the total body sodium content. Assuming no great changes in glomerular filtration rate (GFR), this sort of response might involve diversion into the urine of $5-10 \%$ of the filtered load.

Observations in these assay animals, which indicate that the natriuretic activity of the hormonal substance depends on other factors (e.g. state of sodium balance), are supported by the clinical observations during saline loading. Thus, natriuretic activity appeared in plasma and urine of both the normal and the hypertensive subjects as soon as $30 \mathrm{~min}$ after starting the infusion. However, only some of the hypertensives responded by rapidly excreting large amounts of sodium in the urine, whereas the normal subjects tended to excrete their sodium load much more slowly. These results suggest again that other factors may be involved in the hypertensive subject which allows delivery of more sodium to the site of action of the hormone.
The character of the natriuretic response observed in the assay rat may provide clues about the nature and site of action within the tubule of the natriuretic humor. All positive assays were associated with marked increases in the urine sodium concentration (Fig. 10). Furthermore, there was no apparent association between the magnitude of the natriuresis and changes in urine flow. Because the animals were in water diuresis and could not release $A D H$, these results strongly suggest that the natriuretic substance acts, as least in part, in a distal portion of the tubule where the urine is normally diluted. If the hormonal substance had induced natriuresis by increasing GFR or by depressing proximal tubular reabsorption, urine flow would have been likely to show consistent increases. However, even though a distal site of action is suggested by these data one cannot completely exclude a proximal tubular inhibition as well which might be masked by noxious agents in the extract operating to reduce urine flow by depressing GFR. The rather consistent, albeit slight associated increases in $\mathrm{K}^{+}$excretion observed perhaps suggest a site of action 


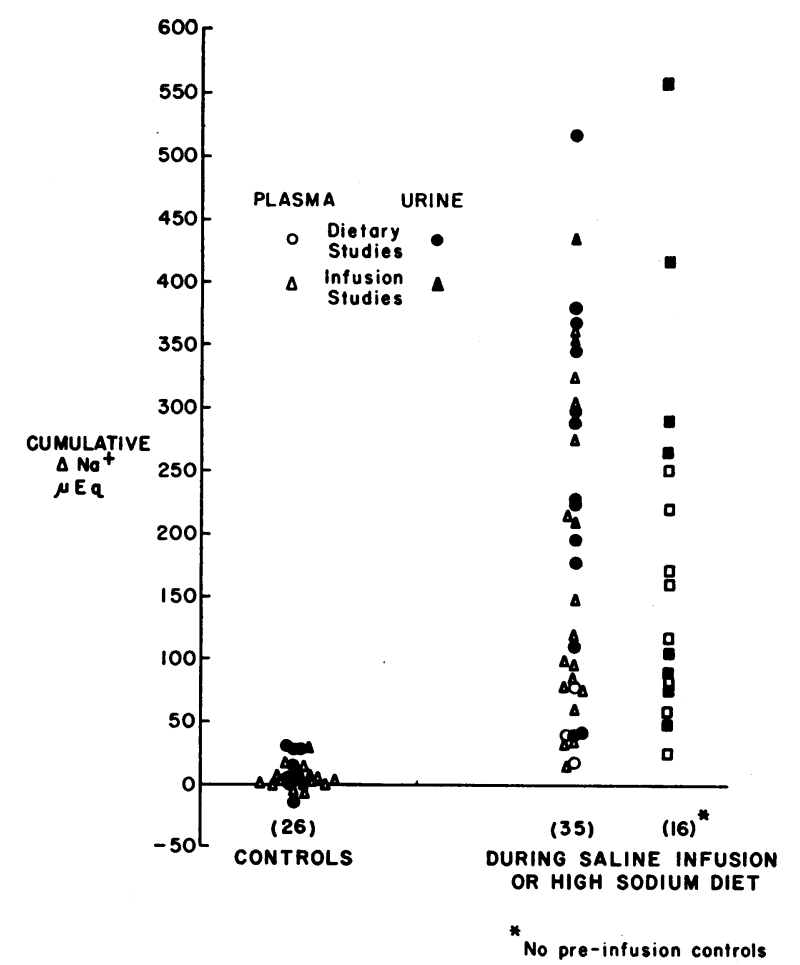

FIGURE 9 Natriuretic assays of plasma and urine fractions. Data from all assays are plotted. 26 control samples prepared from plasma or urine of sodium-depleted subjects or collected before saline infusions consistently failed to affect sodium excretion in the test animals. In sharp contrast, extracts prepared from samples collected during a high sodium diet or after saline infusion all exhibited some degree of natriuretic activity. The natriuretic hormonal agent appeared with saline loading in both normal and hypertensive subjects even though some of the hypertensives excreted saline much more rapidly (cf. Table 4).

proximal to a $\mathrm{K}^{+}$secretory mechanism. Further assays under different physiological circumstances, i.e. hydropenic animals, may prove fruitful in defining nature and site of action. Preliminary results in our laboratory indicate that this natriuretic activity can be demonstrated in hydropenic rats.

The occasionally observed delay in onset of natriuretic activity and its rather prolonged effect for up to $3 \mathrm{hr}$ in the assay animal is worthy of comment. The time delay perhaps suggests that another active substance might be released or that the hormonal agent itself, like aldosterone and some other hormones, must first enter the cells and induce secondary changes. The apparently large size of the present humoral substance may be relevant in this regard because release of a smaller molecule bound to a larger one might also explain the relatively slow kinetics observed.

The fractionation procedures employed suggest that the molecular weight of the active natriuretic material is greater than 5000 and less than 70,000 . Thus, the only active samples were contained in the protein peak on a G25, just behind the protein peak on a G75 and nearer the salt peak on a G100 column. The substance was resistant to boiling and was not inactivated by mercaptoacetic acid. Preliminary studies indicate that it is nondialyzable, and is inactivated by trypsin or by treatment with trichloroacetic acid. Further characterization of the biochemical properties of this natriuretic agent is required.

Many investigators have reported studies which were thought to demonstrate the existence of either a natriuretic or a diuretic factor in plasma or urine. Thus, Milies (27), in an unconfirmed report, described an enormous diuresis with a moderate natriuresis in dogs given a specially prepared globulin extract of liver perfusate. Little has described a diuretic principle in a high molecular weight nondialyzable concentrate of dog or human (28) urine. The extract produced a considerable diuresis and natriuresis in assay dogs. No attempt was made to relate the activity of this material to sodium excretion or metabolism in the subjects from whom it was collected. Kruck (29), following Little's extraction procedure, also demonstrated a diuresis but very little natriuresis in rats given the extract intravenously. These extracts were prepared from hydrated volunteers undergoing natriuresis. Both Little and Kruck used saline-loaded animals and their assay involved the subtraction of control rates of sodium excretion as determined from another study. Jahn, Jahn, Heusner, and Stahl have described a diuretic principle demonstrated by intravenous or intraperitoneal injections into an assay rat of untreated and unconcentrated urine or plasma samples collected from volume expanded dogs or man (30). The activity also appears after hemorrhage in dogs (31). Sodium excretion was not often measured but the increases were small when compared to the diuretic effect. These latter experiments differ from our own because we have not observed any consistent effects after injections of untreated, unconcentrated plasma or urine. Also, we have failed to demonstrate natriuresis after intraperitoneal injections, even when large amounts were given. Furthermore, aur material, unlike that of all of the above workers, has a greater effect on sodium excretion and does not consistently or significantly increase urine flow. While the extraction procedures we employed were quite different, there may in fact be similarites between the material reported by Little (28) and that described herein. Both agents appear to be large molecular weight substances and the time course of the induced natriuresis appears somewhat similar.

Unconvincing evidence for a natriuretic hormone has also been advanced by Cort (8), Cort, Pliška, and Dousa 
(32), and Sedlakova, Lichardus, and Cort (33). Their substance produces very unimpressive increases in sodium excretion. It also differs from the hormonal ma- terial described herein because it is dialyzable and has a molecular weight said to be from 800 to 1000 . Unlike our substance, their agent is resistant to trichloroacetic

TABLE IV

Summary of Assays of Samples Collected before and during Saline Infusions

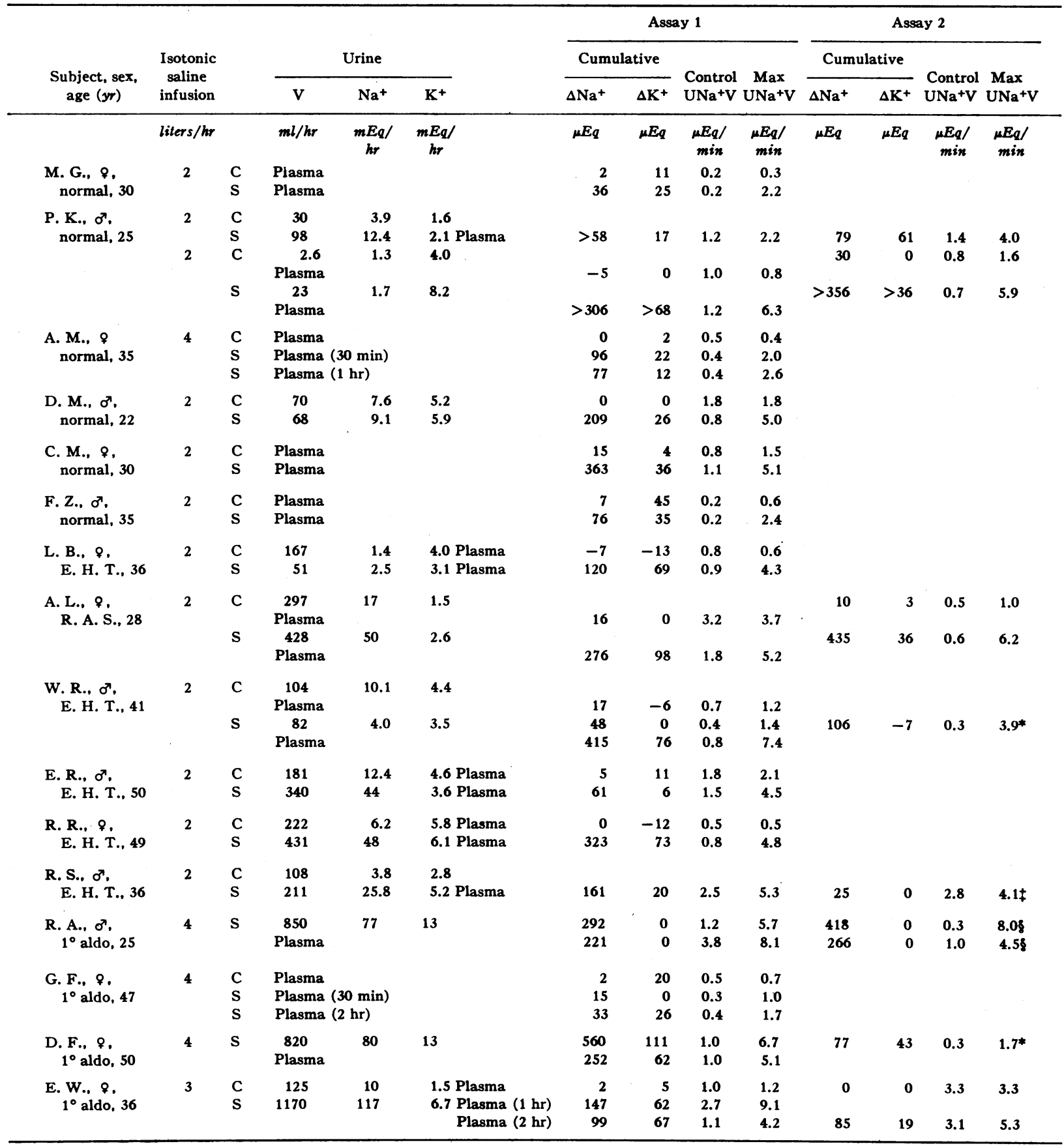

Aldo $=$ aldosteronism $; \mathbf{C}=$ control $; \mathrm{S}=$ saline infusion.

* = 6 min urine extract.

$\ddagger \equiv 2$ cc plasma extract.

$=12$ min urine extract. 
acid, and is not found in mixed venous blood. Their material is said to be secreted somewhere in the head because of its high concentration in jugular vein blood. A substance with physicochemical and physiological properties very similar to the material described by Cort and his coworkers has recently been characterized by Rector and associates (12). Other groups have not been able to confirm these experiments $(34,35)$.

Oxytocin is known to be natriuretic in rats studied under conditions similar to those of the present study (36). This natriuretic effect differs because it is accompanied by antidiuresis and then a diuresis. Also, the fractionation studies and the fact that thioglycollate does not inactivate the natriuretic activity described herein all make it quite unlikely that oxytocin accounts for the results obtained.

A number of investigators have attempted to demonstrate a natriuretic hormone in cross-circulation experiments between saline-loaded animals and either normal recipients $(1,2,10,11,37,38)$ or isolated perfused kidneys $(9,39)$. Some workers seem to have demonstrated convincing changes $(10,11)$. However, in general, the results obtained and the authors' interpretation of the results are not always in agreement (40). A basic problem with these experiments is the fact that renal sodium excretion always increases much more in donor than in recipient dogs. This has led to the sug- gestion that the postulated natriuretic hormone has a very short half-life, an observation not in keeping with our present experiments. An alternate explanation might be that since the recepient animals were not allowed to become volume expanded there was less depression of proximal tubular reabsorption due to physical change in the postglomerular circulation (13). Then less sodium would be delivered to the more distal site of action of the natriuretic hormone. Therefore, although both animals may have been subjected to equal amounts of hormone, the donor animal could be much more receptive to its action. This theory might lead to the conclusion that intrarenal "physical factors" per se could be the "third factor" and that other humoral factors such as the natriuretic substance described herein may constitute a fourth factor involved in regulating sodium excretion. In this context, in studying renal sodium excretion it may be important to recognize that a multifactorial system remains even after the known variables (GFR and aldosterone) have been eliminated (40).

Previous investigations have suggested the head (32), the liver $(27,30,41)$, and the kidney (11) as possible sources for a circulating natriuretic hormone. On the other hand, Levinsky (42) could not abolish saline diuresis by organ ablations. We have not assayed various tissues for the substance described in this communication. However, in sheep no gross differences in

TABLE V

Summary of Assays of Samples Collected from Sheep

\begin{tabular}{|c|c|c|c|c|c|c|c|c|}
\hline \multirow[b]{3}{*}{ Sheep no. } & \multirow[b]{3}{*}{ Regimen } & \multirow{2}{*}{\multicolumn{3}{|c|}{$24 \mathrm{hr}$ urine }} & \multicolumn{4}{|c|}{ Rat assay results* } \\
\hline & & & & & \multicolumn{2}{|c|}{ Cumulative } & \multirow{2}{*}{$\begin{array}{l}\text { Control } \\
\mathrm{UNa}^{+} \mathrm{V}\end{array}$} & \multirow{2}{*}{$\begin{array}{c}\mathrm{Max} \\
\mathrm{UNa}^{+} \mathrm{V}\end{array}$} \\
\hline & & $\mathrm{V}$ & $\mathrm{Na}^{+}$ & $\mathrm{K}^{+}$ & $\Delta \mathrm{Na}^{+}$ & $\Delta \mathrm{K}^{+}$ & & \\
\hline & & $m l$ & $m E q$ & $m E q$ & $\mu E q$ & $\mu E q$ & $\mu E q / \min$ & $\mu E q / \min$ \\
\hline 60 & Low salt & 345 & 14 & 110 & 17 & 0 & 0.5 & 1.0 \\
\hline 59 & High salt, $2 \mathrm{wk}$ & 2800 & 363 & 158 & 974 & 171 & 2.0 & 13.0 \\
\hline 59 & High salt, 2 wk & Plasma & & & 150 & 30 & 0.2 & 3.8 \\
\hline 60 & Low salt & Plasma & & & -46 & 0 & 3.2 & 2.0 \\
\hline 59 & High salt, $3 \mathrm{wk}$ & Plasma & & & 373 & -33 & 2.9 & 8.0 \\
\hline 59 & High salt, $3 \mathrm{wk}$ & 1900 & 431 & 160 & 480 & 139 & 1.3 & 19.5 \\
\hline 59 & High salt, 5 wk & 1850 & 352 & 170 & 1004 & 89 & 1.2 & 12.6 \\
\hline 59 & Low salt & Plasma & & & 16 & 7 & 0.5 & 1.4 \\
\hline 59 & High salt, $6 \mathrm{wk}$ & Plasma & & & 383 & 20 & 2.5 & 20.0 \\
\hline 59 & Low salt & Jugular vein & & Plasma & 0 & 0 & 0.8 & 0.8 \\
\hline 59 & High salt & Jugular vein & & Plasma & 151 & 50 & 1.1 & 3.8 \\
\hline 59 & High salt & Femoral vein & & Plasma & 57 & 105 & 0.8 & 2.6 \\
\hline 60 & Normal salt & 425 & 80 & 82 & 164 & 0 & 5.6 & 6.2 \\
\hline 60 & High salt, 4 days & 900 & 215 & 118 & 562 & 0 & 4.8 & 26.0 \\
\hline
\end{tabular}

* Results presented as groups obtained from each assay animal. 


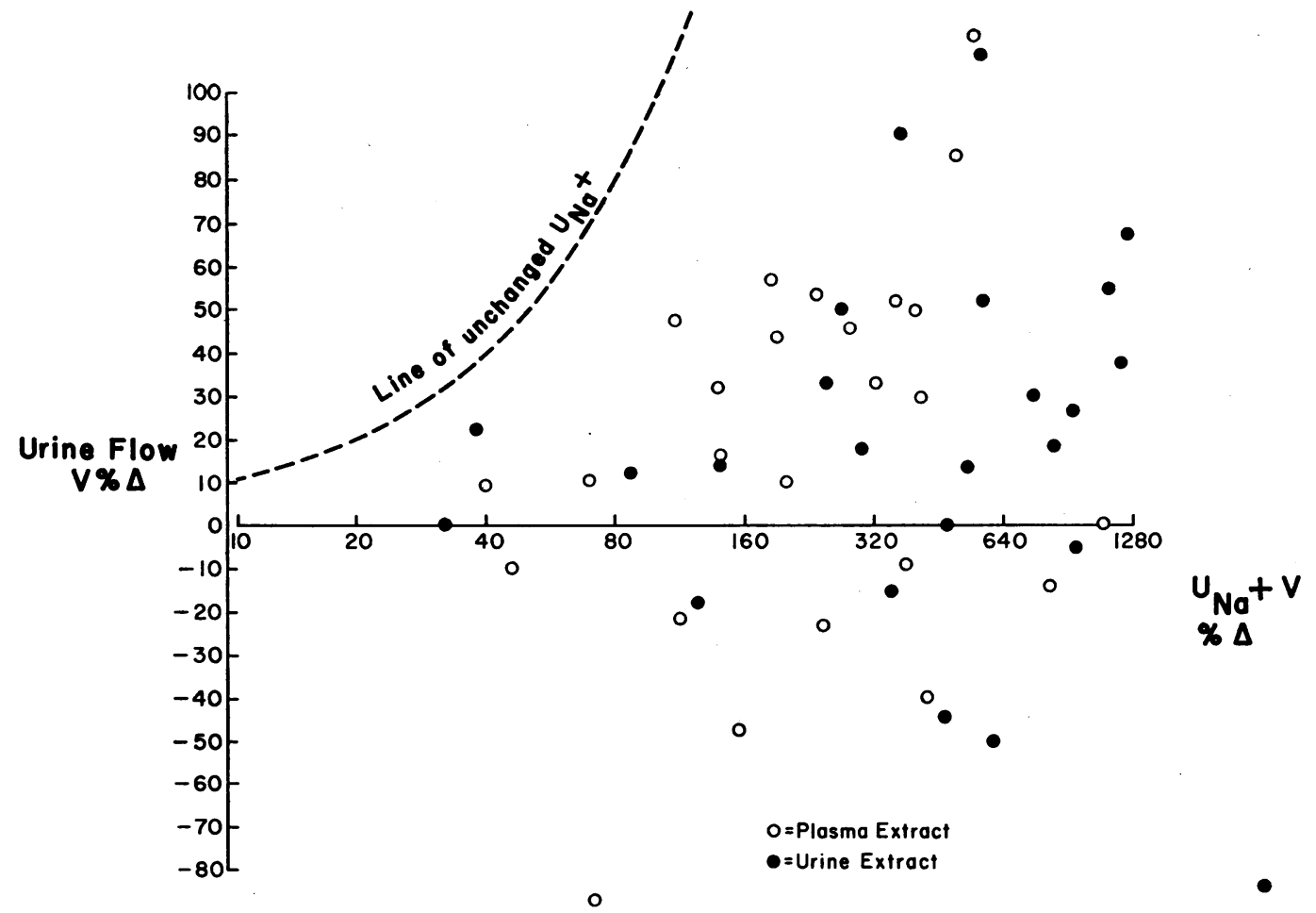

FIgURE 10 This graph presents the relationship between the per cent change in urine flow and the per cent change in the rate of sodium excretion plotted on a logarithmic scale. Data are presented from all positive natriuretic assays. The curved line represents those increases in $\mathrm{U}_{\mathrm{Na}}{ }^{+} \mathrm{V}$ in which the only component which increased is the urine flow. Any points in which there was an increase in sodium concentration fall to the right of this line.

natriuretic activity were observed in femoral when compared to jugular venous blood.

The effect of this natriuretic agent on renal hemodynamic remains to be investigated. Some of its effects might result from an action to increase GFR or renal blood flow even though, for reasons given above, this seems unlikely. Numerous assays indicate that the active substance induces no significant changes in arterial pressure in assay animals undergoing natriuresis.

\section{ACKNOWLEDGMENTS}

We wish to thank Mr. Hector Hernandez for his excellent assistance in breeding the rats with hereditary diabetes insipidus.

This work was supported by U. S. Public Health Service Research Grant HE-01275-18.

\section{REFERENCES}

1. De Wardener, H. E., I. H. Mills, W. F. Clapham, and C. J. Hayter. 1961. Studies on the efferent mechanism of sodium diuresis which follows the administration of intravenous saline in the dog. Clin. Sci. 21: 249.

2. Mills, I. H., H. E. De Wardener, C. J. Hayter, and W. F. Clapham. 1961. Studies on the afferent mechanism of the sodium chloride diuresis which follows intravenous saline in the dog. Clin. Sci. 21: 259.
3. Levinsky, N. G., and R. C. Lalone. 1963. The mechanism of sodium diuresis after saline infusion in the dog. J. Clin. Invest. 42: 1261.

4. Blythe, W. B., and L. G. Welt. 1963. Dissociation between filtered load of sodium and its rate of excretion in the urine. J. Clin. Invest. 42: 1491.

5. Rector, F. C., Jr., G. Van Giesen, F. Kiil, and D. W. Seldin. 1964. Influence of expansion of extracellular volume on tubular reabsorption of sodium independent of changes in glomerular filtration rate and aldosterone activity. J. Clin. Invest. 43: 341.

6. Stein, R. M., D. D. Bercovitch, and M. D. Levitt. 1964. Dual effects of saline loading on renal tubular sodium reabsorption in the dog. Amer. J. Physiol. 207: 826.

7. Bricker, N. S. 1967. The control of sodium excretion with normal and reduced nephron populations. Amer. J. Med. 43: 313.

8. Cort, J. H. 1965. Electrolytes, Fluid Dynamics and the Central Nervous System. Academic Press Inc., New York.

9. Lichardus, B., and J. W. Pearce. 1966. Evidence for a humoral natriuretic factor released by blood volume expansion. Nature (London). 209: 407.

10. Johnston, C. I., and J. O. Davis. 1966. Evidence from cross-circulation studies for a humoral meshanism in the natriuresis of saline loading. Proc. Soc. Exp. Biol. Med. 121: 1058.

11. Johnston, C. I., J. O. Davis, S. S. Howards, and F. S. Wright. 1967. Cross-circulation experiments on the 
mechanism of the natriuresis during saline loading in the dog. Circ. Res. 20: 1.

12. Rector, F. C., Jr., M. Martinez-Maldonado, N. A. Kurtzman, J. C. Sellman, F. Oerther, and D. W. Seldin. 1968. Demonstration of a hormonal inhibitor of proximal tubular reabsorption during expansion of extracellular volume with isotonic saline. J. Clin. Invest. 47: 761.

13. Daugharty, T. M., L. J. Belleau, J. A. Martino, and L. E. Earley. 1968. Interrelationship of physical factors affecting sodium reabsorption in the dog. Amer. J. Physiol. 215: 1442.

14. Lewy, J. E., and E. E. Windhager. 1968. Peritubular control of proximal tubular fluid reabsorption in the rat kidney. Amer. J. Physiol. 214: 943.

15. Brenner, B. M., K. H. Falchuk, R. I. Keimowitz, and R. W. Berliner. 1969. Relationship between peritubular capillary protein concentration and fluid reabsorption by the rat proximal tubule. J. Clin. Invest. 48: 11a.

16. Barger, A. C. 1966. Renal hemodynamic factors in congestive heart failure. Ann. N. Y. Acad. Sci. 139: 276.

17. Horster, M., and K. Thurau. 1968. Micropuncture studies on the filtration rate of single superficial and juxtamedullary glomeruli in the rat kidney. Pfluegers Arch. Gesamte Physiol. Menschen Tiere. 301: 162.

18. Stein, J. H., L. J. Barton, H. Mandin, L. H. Lackner, F. C. Rector, Jr., and D. W. Seldin. 1969. Effect of extracellular volume expansion on proximal tubular sodium reabsorption and distribution of renal blood flow and glomerular filtrate in the dog. Clin. Res. 17: 449. (Abstr.)

19. Dirks, J. H., W. J. Cirksena, and R. W. Berliner. 1965. The effect of saline infusion on sodium reabsorption by the proximal tubule of the dog. J. Clin. Invest. 44: 1160 .

20. Howards, S. S., B. B. Davis, F. G. Knox, F. S. Wright, and R. W. Berliner. 1968. Depression of fractional sodium reabsorption by the proximal tubule of the dog without sodium diuresis. J. Clin. Invest. 47: 1561.

21. Valtin, H. 1967. Hereditary hypothalamic diabetes insipidus in rats (Brattleboro strain). Amer. J. Med. 42: 814.

22. Sawyer, W. H. 1961. Biologic assays for oxytocin and vasopressin. In Methods in Medical Research. Yearbook Medical Publishers, Inc., Chicago. 9: 210.

23. Wilson, D. R., G. Thiel, M. L. Arce, and D. E. Oken. 1969. The role of the concentration mechanism in the development of acute renal failure: micropuncture studies using diabetes insipidus rats. Nephron. 6: 128.

24. Laragh, J. H., J. E. Sealey, and S. C. Sommers. 1966. Patterns of adrenal secretion and urinary excretion of aldosterone and plasma renin activity in normal and hypertensive subjects. Circ. Res. Suppl. 1. 18 and 19: 1158.

25. Newton, M. A., and J. H. Laragh. 1968. Effect of corticotropin on aldosterone excretion and plasma renin in normal subjects, in essential hypertension and in primary aldosteronism. J. Clin. Endocrinol. Metab. 28: 1006.

26. Gocke, D. J., J. Gerten, L. M. Sherwood, and J. H.
Laragh. 1969. Physiological and pathological variations of plasma angiotensin II in man. Circ. Res. (Suppl. 1) 24 and 25: $1-131$.

27. Milies, E. 1960. A new diuretic factor of hepatic origin. Acta Physiol. Latinoamer. 10: 178.

28. Little, J. M. 1965. Renal hemodynamic and electrolyte excretion effects of the urinary diuretic factor (UDF). J. Pharmacol. Exp. Ther. 148: 363.

29. Kruck, F. 1967. Biologischer Nachweis eines humoralen natriuretischen prinzips im urin gesunder menschen. Klin. Wochenschr. 45: 30.

30. Jahn, H., M. Jahn, A. A. Heusner, and J. Stahl. 1967. Mise en évidence chez l'homme et chez le chien d'un facteur diurétique et natriurétique dans le sang et les urines après expansion du volume extracellulaire. C. R. Acad. Sci (Paris). 265: 1145.

31. Jahn, H., F. Stephan, and J. Stahl. 1960. Activite diuretique dans le sang et les urines apres saignee chez le chien. Arch. Sci. Physiol. 14: 421.

32. Cort, J. H., V. Pliška, and T. Douša. 1968. The chemical nature and tissue source of natriuretic hormone. Lancet. $1: 230$.

33. Sedláková, E., B. Lichardus, J. H. Cort. 1969. Plasma saluretic activity: its nature and relation to oxytocin analogs. Science (Washington). 164: 580.

34. Wright, F. S., B. M. Brenner, C. M. Bennett, R. I. Keimowitz, R. W. Berliner, R. W. Schrier, P. J. Verroust, $H$. E. de Wardener, and $H$. Holzgreve, 1969. Failure to demonstrate a hormonal inhibitor of proximal sodium reabsorption. J. Clin. Invest. 48: 1107.

35. Bank, N., K. M. Koch, H. S. Aynedjian, and M. Aras. 1969. Effect of changes in renal perfusion pressure on the suppression of proximal tubular sodium reabsorption due to saline loading. J. Clin. Invest. 48: 271.

36. Chan, W. Y. 1965. Effects of neurohypophysial hormones and their deamino analogues on the renal excretion of sodium, potassium and water in rats. Endocrinology. 77: 1097.

37. McDonald, M., R. W. Schrier, and D. P. Lauler. 1967. Effect of acute extracellular volume expansion on crosscirculated dogs. Nephron. 4: 1 .

38. Pearce, J. W., H. Sonnenberg, A. T. Veress, and U. Ackerman. 1969. Evidence for a humoral factor modifying the renal response to blood volume expansion in the rat. Can. J. Physiol. Pharmacol. 47: 377.

39. Tobian, L., K. Coffee, and P. McCrea. 1967. Evidence for a humoral factor of non-renal and non-adrenal origin which influences renal sodium excretion. Trans. Ass. Amer. Physicians Philadelphia. 80: 200.

40. Berliner, R. W. 1968. Intrarenal mechanisms in the control of sodium excretion. Fed. Proc. 27: 1127.

41. Stahl, J., H. Jahn, M. Jahn, and R. Kieny. 1968. Origine hepatique du facteur diuretique et natriuretique produit par stimulation des volorecepteurs intrathoraciques (respiration en pression negative). C. R. Acad. Sci (Paris). 162: 264

42. Levinsky, N. 1966. Non-aldosterone influences on renal sodium transport. Ann. New York Acad. Sci. 139: 295. 